\title{
The development trend of foreign electric power market and
}

\section{Enlightenment}

\author{
Wei Zhao and Fangyun Li \\ Institute of Technology.East China Jiaotong University Jiangxi Nanchang 330100
}

Keywords: electric power industry reform; vertical monopoly;market competition

\begin{abstract}
: from the view of the world, the electric power industry reform began in 1981 in chile. But this reform developed into a world of reform movement isstarted after the power industry reform in the late 80 's britain.

From the view of the world, the electric power industry reform began in 1981 in chile. But this reform developed into a world of reform movement is started after the power industry reform in the late 80 's britain.
\end{abstract}

\section{Reform the mode of world power}

World differences in management mode of electric power industry is large, and is closely related to the domestic economy development level, economic development level, forms of ownership, etc.. To sum up, about the followingseveral models:

(1) a single vertical monopoly mode: the national power generation,transmission, power distribution business is operated entirely by an electric power company, for state owned enterprises, by the national power companyto implement the control of management, France, Italy, Portugal, Greece and other countries belong to this type.

(2) long monopoly mode: this mode has two kinds of situations, the first kind is the multi vertical monopoly, is composed of a plurality of power companydivision management, each regional electricity supply is relatively independent,power generation, transmission, distribution under vertical integrationmonopoly, the district power network is connected. Japan is a typical use of this model, a top 10 national power company, in addition to Okinawa Electric Power Co, the other 9 major power companies have network with each other.Second is the number of power monopoly, distribution business by othercompanies, transmission network is the internet. At present, the electric power industry in California using this model.

(3) single monopoly and multiple combination model: transmission businessfrom a single power company, and the vertical management of power generation and distribution business, power generation and distribution also allows other firms to enter, but because the power transmission companymonopoly advantage, to ensure fair competition, the state regulation of electric power company, the current power enterprises in Germany, USA this is themanagement pattern.

(4) the open market competition mode: full implementation of competition in the generation, placing the electric field, the transmission by a company's business, and government supervision. This mode is mostly formed nearly 10 years after the reform of electric power industry in the world, with the UK,Australia, Argentina, Chile, Norway, New Zealand, Singapore, Holland and other countries as the representative.

In the electric power system reform in the world and the establishment of the electricity market model, the basic trend of the global power industry reform isto break the monopoly, the formation mechanism of competition has become an inevitable trend. But the characteristics of power industry, transportation, and send the request for completion and to serve the public, to break the monopoly of the method is not the simple open, also is not the "laissez faire"market. The power industry 
restructuring should make shareholder value,service quality and price level to achieve the optimal balance, maximize the total value of the three party.

\section{Characteristics of foreign electric power reform}

The electric power industry is the public utility has its particularity, therefore,even in the market economy system perfect, the organization form and the operation mechanism of the electric power industry is to distinguish the particularity in the general competition in the industry and the long-term existence. Promote and makes the reform success there are two main reasons: one is the external pressure, i.e., the society to improve the efficiency of power industry requirements, because the monopoly is easy to make the enterprise management and market pressure disjunction, resulting in high cost and low efficiency, resulting in price rises, the society is to promote the reform of the external conditions on the to improve the efficiency of the electric power industry requirements. Two is the reform and material conditions, namely thedevelopment of the power grid security technology, the power in the hair,transmission, distribution and sale of separate and develop competitive conditions, still can maintain stable and safe production and supply.

The process of foreign electric power reform is generally introduced by the government reform, scheme design and set up an authoritative organizationreform, and the drafting of the relevant policies and regulations, then the power companies of the integration of traditional decomposition, and set up amechanism to supervise to the competition.

The power industry restructuring has no ready-made model to copy, a state of the industry pattern depends on the country's electricity industrycharacteristics and the political, economic and social factors and so on. The world is not a perfect reform mode of electric power industry, power industryreform should seek truth from facts, from the actual situation.

\section{Enlightenment of experience of foreign electric power reform to China}

(1)Objective should have a clear understanding of the reform of electric power, todetermine the reform steps and methods:

Objective to reform in different periods of different countries are different. The different reform objective, reform will bring the methods and steps of different. The purpose of power reform in Britain, one is to bring benefits to users, the two is to improve efficiency, the three is to improve the social benefit. The best way to realize this objective is the wide competition, promote the cost and the price to fall, give users more rights and better new services, users become the first beneficiaries, which is not only the guarantee of safety. To break the monopoly, encourage competition, improve efficiency, reduce the price,improving service, has become the most state power industry reform direction.

For the power industry reform in our country, is important to face thedisadvantages of generation investment diversification and vertical integrationmanagement reality, through asset restructuring, the introduction of competition mechanism in the field of power generation, fully reflect the fair,just and open principles, and improve national control on power grid. This and other countries reform is not the same. Improvement will bring cost reduction,price reduction and service level of course competition results.

(2)Establishment of power market, the introduction of competition mechanism, notone size fits all, rushing headlong into mass action, and should emancipate the mind, seek truth from facts:

At present, China's resources are not fully effective use. Therefore, to optimize the allocation of resources, obtain the power balance in the greater region,established a solid network, is the implementation of the outstanding problems in the reform. The reform of the electricity market is advancing in thecontinuous improvement in the. For the reform of power market, we should start 
currentgeneration:

(1) Net factory are separated by a separate operating mode as the starting point,with property right separation as the end point, no property right separation is hard to say fair competition.

(2) Hydropower plants and key power grid should be mastered, which plays an important role in the safe operation of the power grid in the competition.

(3)Electric power system reform should be government led,legislation:

The reform is to adapt to the need of the development of productive forces to adjust the relations of production, will inevitably involve the redistribution of power and interests, thus encountered some resistance, at the same time, the reform also need cost. Therefore, reform must be carried out under the unified leadership of the government, under the coordination, can not go one's own way. That the British and Australia practice, the governments of the two countries play an active leading role by direct and indirect ways in the reform of electric power, a major decision before all pass system analysis and careful argumentation, and to fulfill the legal procedures, the two countries reformprogress, continue to reduce costs, one of the decisive factors that effect moreobvious.

(4)Must establish the matching market rules and regulatory system:

Foreign legislation first, after the experience of reform, in the present situation of our country is very difficult to do. But the legislative consciousness should be implemented in the whole process of electric power system reform, through the reform of certain things should be as soon as possible by laws or regulations or the form of fixed, timely amend the relevant laws or regulations,in order to ensure the smooth progress of reform. The rules of the market and supervision holds the extremely important status in the establishment of the electricity market competition, especially in China's legal system is not perfect,not matching conditions, a sound regulatory mechanism is particularly important.

In addition, we also deal with the supervision mode of in-depth study. It should be said that the reform model is different, the regulation on electricity marketare not the same. The grid is owned by the state or the holding of the national,the power grid scheduling, power market and power network operationbusiness management, to accept the strict supervision of the state, at the same time, the country still to transmission and distribution price regulation.For example, the British model is taken, the electricity market is strictly regulated by a government agency OFFER.

(5)Power market reform is a gradual, continuous developmentand improvement process:

From the overseas reform situation, the electricity market reform is a gradual process, involving the system, mechanism, policy, ideas and habits, especially with China's current reform of the entire economic system and political and economic stability is closely related to. Therefore, the reform of electric powershould be timely, gradual reform in to protect the power investors, operatorsand users of the legitimate rights and interests of all aspects, to ensure the stability of.In our country at present is concerned, the power generation sector is nonmonopoly, should be strictly regulated. When the transformation and construction of urban and rural power grid reached a certain level, can consider to use separate electric business and distribution business. The distribution business is a monopoly, electric business should competition.Finally, transmission and distribution separation, the establishment of a unified national electricity market open, competitive and orderly.

(6)Reform must ensure the safety of the grid:

No true security issues are closely related to the economic efficiency of enterprises, users and social benefits. Therefore, the compensation problemseriously study the reactive power, voltage, AGC ancillary service system in the grid to the trading mode and operation rules, can be simple to complex,must establish the reactive power status and price. Because it is related to the safe and stable operation of power grid, so all countries on the issue of compensation ancillary service. To 
adhere to the principle of unified scheduling in grid scheduling. The United Kingdom, Argentina, Chile iseconomic dispatch, and the British scheduling belongs to the power grid enterprises, further reform of the current power market or so.

\section{Conclusion}

To sum up, with the rapid development of global economy, the global scope of the reform of electric power market construction situation has a huge change, plays an important role in the overall development direction of electric power industry. The trend of the latest development of the power market of domestic and foreign power market analysis and research and inspiration, puts forward and analyzes some effective strategies to accelerate the development process of the electric power market. It is easy to know that China must build in line with China's national conditions, low-carbon energy market is necessary. The pace of development more and more quickly, the construction of talent more and more challenges, the requirements of power market personnel should have certain professional knowledge, actively coordinate with the staff, to meet the needs of the masses, establish a good corporate image, maintain the long-term development of enterprises.

\section{References}

[1] Canada in Ontario province electricity market reform enlightenment of Liu Gang [J].. Chinese 2006 (07) prices.

[2] power market operation mode and market structure of [J]. Liu Qiuhua, Han Yu. Commercial research. 2006 (13)

The special effects of [3] China power on the structure of the power market of [J]. Li Daoqiang, Wu Xiaobo. The economic and management research technology 2004 (04).

The reform and reorganization of [J]. I.M. sakhaee, [4] India electric power department to hydropower energy. 2004 (15) express.

The operation and management of Australia [5] power market and Its Enlightenment to China [J]. Li Dajun, Li Jiabin, Hao. Zeming Jilin power 2004 (03).

[6] Texas electric power market mode and its information technology (IT) by [J].. Wei porphyrite international power 2004 (01).

[7] China power market structure the strategic choice of [J]. technology. Que brilliant economic power $2004(01)$. 